$10-2016$

\title{
Genocide Denial: Perpetuating Victimization and the Cycle of Violence in Bosnia and Herzegovina (BiH)
}

Genevieve Parent

Saint Paul University

Follow this and additional works at: https://digitalcommons.usf.edu/gsp

\section{Recommended Citation}

Parent, Genevieve (2016) "Genocide Denial: Perpetuating Victimization and the Cycle of Violence in Bosnia and Herzegovina (BiH)," Genocide Studies and Prevention: An International Journal: Vol. 10: Iss. 2 : 38-58.

DOI:

http://dx.doi.org/10.5038/1911-9933.10.2.1369

Available at: https://digitalcommons.usf.edu/gsp/vol10/iss2/6

This Articles is brought to you for free and open access by the Open Access Journals at Digital Commons @ University of South Florida. It has been accepted for inclusion in Genocide Studies and Prevention: An International Journal by an authorized editor of Digital Commons @ University of South Florida. For more information, please contact digitalcommons@usf.edu. 


\title{
Genocide Denial: Perpetuating Victimization and the Cycle of Violence in Bosnia and Herzegovina (BiH)
}

\author{
Genevieve Parent \\ Saint Paul University \\ Ottawa, Ontario, Canada
}

\begin{abstract}
The denial of the Armenian genocide led to devastating effects on both the individual and collective levels which in many cases were passed down to their descendants. In BiH, many of the facts are not denied per se but the interpretation is such that genocidal intent is denied. While some research has been done on the consequences of trauma among BiH survivors, no in-depth studies are found on the effects of denial on the survivors' psychosocial well-being. This article aims to fill in the gaps based on in-depth-interviews carried out since 2011 in BiH, investigating the cognitive, affective and behavioral consequences of denial at both the intragroup and intergroup levels. This article also seeks to identify which forms of acknowledgement are the most meaningful to the survivors for preventing further victimization. Finally, this article examines the interconnection which exists between denial and acknowledgement for reconciliation and sustainable peace to occur.
\end{abstract}

Keywords: genocide, accountability, psychosocial rehabilitation, reconciliation

\section{Introduction}

During the 1992-1995 war in Bosnia-Herzegovina (BiH), approximately 104,732 individuals perished or disappeared, ${ }^{1} 350,000$ were wounded, ${ }^{2} 20,000$ to 60,000 women were raped ${ }^{3}$ and 8,000 Muslim men and boys died in Srebrenica. ${ }^{4}$ Former US Secretary of State Lawrence Eagleburger reported that numerous charges were laid against the Serbs, and had expressed "the facts of which are indisputable." 5 The information was delivered to the UN War Crimes Commission responsible for deciding whether to prosecute or not. Among the charges: the siege of Sarajevo (which, lasted 44 months, killed more than 11,000 and wounded another 50,000, including children); the attacks (bombings, beatings and killings) of Banja Luka's 30,000 Bosniaks; the concentration camps in Banja Luka/Makaca, Brčko/ Luka, Krajina, Prnjavor, Moarska, Prijedor/ Keraterm, Trnopolje/Kozarac; the massacres of between 2,000 and 3,000 Muslim men and boys at a brick factory and a pig farm near Brčko. ${ }^{6}$

A report by Tabeau, Żołtkowski, Bijak and Hetland presented in the International Criminal Tribunal for the former Yugoslavia (ICTY) shows that extreme changes occurred to the Muslim population living in the "Milošević case area."7 The number of Bosniaks in seven municipalitiesthat are now part of the Republic of Srpska - was reduced by approximately 91.4 to $99.9 \%$ between 1991 and 1997-1998. To illustrate the point, in 1997-1998, ten Muslim individuals were identified in

${ }^{1}$ Jan Zwierzchowski and Ewa Tabeau, "The 1992-95 War in Bosnia and Herzegovina: Census-Based Multiple System Estimation of Causalities' Undercount." Conference Paper for the International Research Workshop on The Global Costs of Conflict (Berlin: The Households in Conflict Network and The German Institute for Economic Research, 2010).

${ }^{2}$ The Center for Justice and accountability (CJA), Bosnia and Herzegovina: Torture and Ethnic Cleansing in the Bosnian War (San Francisco: The Center for Justice and Accountability, 2014), accessed March 5, 2015, http://www.cja.org/article. php?id=247.

${ }^{3}$ Michele Lent Hirsch, “Conflict Profile: Bosnia," WMC's Women Under Siege Project (US: The Women's Media Center, 2012), accessed February 11, 2015, http://www.womenundersiegeproject.org/conflicts/profile/bosnia.

${ }^{4}$ United States Holocaust Memorial Museum (USHMM), Confront Genocide-Cases-Bosnia Herzegovina (Washington DC: USHMM, 2015), accessed May 8, 2015, http://www.ushmm.org/confront-genocide/cases/bosnia-herzegovina. More specifically, the Srebrenica - Potocari Memorial and cemetery for the victims of the 1995 genocide indicates that at least 8,372 men and boys were killed. See http://www.potocarimc.org/.

${ }^{5}$ Lawrence Eagleburger, "The need to respond to war crimes in the former Yugoslavia," The path to The Hague, Selected documents on the origins of the ICTY, Statement at the International Conference on the Former Yugoslavia (Switzerland: December 16 1992), accessed February 2, 2015, http://www.h-net.org/ fisher/bosnia/readings/Eagleburger1.html.

${ }^{6}$ Ibid.

${ }^{7}$ Ewa Tabeau et al., "Ethnic Composition, Internally Displaced Persons \& Refugees from 47 Municipalities of Bosnia and Herzegovina 1991 to 1997-8: Expert Report for the Case of Slobodan Milosevic (IT-02-54), " in Conflict in Numbers: Casualties of the 1990s Wars in the Former Yugoslavia (1991-1999), ed. Ewa Tabeau (Belgrade: Helsinki Committee for Human Rights in Serbia, 2009): 661-875. accessed 17 June, 2015, www.helsinki.org.rs/doc/testimonies33.pdf; See report for the list of (pre-Dayton) municipalities included in the Milošević case area. 
Bratunac (formerly 16,284), six in Foča (formerly 14,559), seven in Srebrenica (formerly 21,361) and three in Višegrad (formerly 11 178). In Bijeljina, the Muslim population went from 24,314 (1991) to 1,429 (1997-1998). In Brčko, the number of Bosniaks declined from 20,309 to 546, as was the case in Prijedor where the number of Bosniaks declined from 40,075 to 397 in the same period. In Doboj (RS), the number of Bosniaks went from 23,406 to 239, and similarly in Zvornik, from 29,452 to $129 .{ }^{8}$ Due to Milošević's death, no final judgment was reached in Prosecutor $v$. Slobodan Milošević. However, the Trial Chamber rejected Milosevic's "motion for judgment of acquittal" and concluded that genocide had in fact been committed in Bijeljina, Bosanski Novi, Brčko, Ključ, Prijedor, Sanski Most, and Srebrenica. ${ }^{9}$

A vast body of literature indicates that while the Serbs are not the only ones who committed crimes of war, they are the primary perpetrators of the 1990's wars in ex-Yugoslavia, where the disproportionate suffering experienced by Bosniaks is indisputable. ${ }^{10} \mathrm{In} \mathrm{BiH}$, many of the facts regarding the killings are not denied per se but the interpretation is such that genocidal intent is effectively denied. While some research in clinical, social psychology and psychiatry has been done on the consequences of trauma among BiH survivors, ${ }^{11}$ no in-depth studies are found on the effects of denial on the survivors' psychosocial well being. The present article seeks to fill this gap in knowledge by investigating the cognitive, affective and behavioral consequences of denial at both the intragroup and intergroup levels in the aftermath of genocide. This article is essentially based on multiple interviews that were carried out in person during the course of several field research trips in $\mathrm{BiH}$, Croatia and Serbia between April 2011 and July 2015. The interviews ranged from non-directive to semi-directive and focused predominantly on the accounts of the survivors of war from different municipalities of the Federation of Bosnia and Herzegovina. In most cases, volunteer translators assisted the researcher / interviewer. At other times, a local translator was employed. The respondents were recruited via snowball sampling. This ongoing study makes use of phenomenology both as an approach and as a methodology, where the object of study is understood via the perspective of the lived experience of the survivors. ${ }^{12}$

Following a discussion on the definitions and classifications of denial, this article explores its psychosocial effects, as experienced by the survivors interviewed in $\mathrm{BiH}$. This article also seeks to identify the most meaningful forms of acknowledgement for the survivors in $\mathrm{BiH}$, as it pertains to minimizing or preventing further victimization. Finally, this article examines the interconnection, which must exist between denial and acknowledgement for reconciliation and sustainable peace to occur. Without a good enough acknowledgement, the healing process is delayed or impeded, and retraumatization occurs.

\section{Defining and Classifying Denial}

The strategy of genocide denial is usually conceived of and carried out by the perpetrators, their successors as well as by individuals who support the perpetrators in their attempts to distort the truth and to persecute the victims yet again. ${ }^{13}$ Many types and classifications of denial are found

\footnotetext{
${ }^{8}$ See report by Tabeau et al. (2003) for more results and details

${ }^{9}$ Prosecutor v. Slobodan Milošević: Decision on Motion for Judgment of Acquittal, Kosovo, Croatia \& Bosnia, Trial Chamber, January 16, 2004, IT-02-54-T.

${ }^{10}$ See for instance, Tabeau et al. “Ethnic Composition, Internally Displaced Persons, 661-875; Edina Bećirević, Genocide on the Drina River (New Haven: Yale University Press, 2014); Hariz Halilovich, Places of Pain (New York: Berghahn Books, 2013); Lara J. Nettelfield, Courting Democracy in Bosnia and Herzegovina: The Hague Tribunal's Impact in a Postwar State (New York: Cambridge University Press, 2013); Smail Čekić, Research of Genocide Victims, with a Special Emphasis on Bosnia and Herzegovina. (Sarajevo: University of Sarajevo, 2009); David Campbell, National Deconstruction: Violence, Identity, and Justice in Bosnia (Minneapolis: University of Minnesota Press, 1998).

${ }^{11}$ Johanna Ray Vollhardt and Michal Bilewicz, "After the Genocide: Psychological Perspectives on Victim, Bystander, and Perpetrator Groups," Journal of Social Issues 69, no.1 (2013): 1-15.

${ }^{12}$ For more details regarding phenomenology, please consult Frederick J. Wertz et al., Five ways of doing: Qualitative analysis (New York: The Guilford Press, 2011); Darren Langdridge, Phenomenological psychology (England: Pearson-Prentice Hall, 2007).

${ }^{13}$ Israel Charny, "Classification of denials of the Holocaust and other genocides" in The genocide studies reader, eds. Samuel Totten and Paul R. Bartrop (New York: Routledge, 2009), 517-518.
} 
in the literature but Stanley Cohen and Israel Charny's definitions and classifications are the most comprehensive to date. Stanley Cohen essentially defines denial as 1) an unconscious process or a defense mechanism that blocks off unimaginable and intolerable information to prevent it from reaching the conscious awareness and 2) as a conscious and deliberate choice to ignore reality or facts deemed counter to one's comfort or advantage, purposes and/or needs. ${ }^{14}$ Cohen explains that one's awareness of what is being evaded may be ambiguous. ${ }^{15}$ He adds that the knowledge of atrocities and suffering entails significant "grey areas between consciousness and unconsciousness." 16

Cohen indicates that three forms of denial are possible with respect to what is being denied: literal, interpretative and implicatory. ${ }^{17}$ Literal denial implies that the knowledge or the raw facts are blatantly denied: "nothing happened," "there was no massacre."18 With interpretative denial, the raw facts are not denied but are attributed a different meaning: "it was population exchange" ${ }^{19}$ or "collateral damage" (and not a massacre).$^{20}$ Implicatory denial refers to the denial or the minimization of its significance or of its implications: "these killings have nothing to do with me," "why should I risk my life to intervene" or "it is worse elsewhere." ${ }^{21}$ The author also assigns a psychological status to each type of denial. Literal denial may be a manifestation of genuine ignorance, a deliberate escape from an unbearable reality, or a calculated lie or disinformation. Interpretative denial can be linked to the incapacity to understand the meaning of the facts. It can also assign a different label in order to avoid social marginalization and legal accountability. Implicatory denial involves a degree of sincerity as well as the use of simple techniques to avoid psychological or moral demands related to the events in question. Cohen adds that denial entails cognition (no acknowledgement of the facts), emotion (not feeling disturbed), morality (no recognition of responsibility or of immorality), and action (perpetuating the violence or not acting on known facts). The author also allocates different levels (personal, official, cultural), different time frames (historical, contemporary), different agents (perpetrator, victim and bystander) and space (your own space, elsewhere) to denial..$^{22}$

Israel Charny's classification groups forms of denial into six broad groupings. The category "malevolent bigotry" is associated with denials by perpetrators, non-perpetrators (fascism culture), groups that have been or are victim of genocide, and groups that are vulnerable to genocide because they are weaker (power imbalance) or they committed genocide. ${ }^{23}$ "Self-serving opportunism" constitutes another category and comprises denials that indulge individual or collective self-interest or power e.g. "careerism, pragmatism, exhibitionism and realpolitik." 24 The category "'innocent denials' and/or 'innocent disavowals of violence'" consists of innocent denials via manipulation and lies to eradicate the knowledge or the credibleness of genocide. ${ }^{25}$ "'Definitionalism' or insistence on defining cases of mass murder as not genocide" is a category where denials are based on the definition of genocide and the cases it may include (or not) or the reduction of the significance of a genocide by relativizing, minimizing or rationalizing the events of genocide. ${ }^{26}$ The "nationalistic hubris or self-involvement which justify exclusion of others" category encompasses denials of the facts of genocide of others or of specific groups in particular. ${ }^{27}$

\footnotetext{
${ }^{14}$ Cohen, States of Denial, 5.

${ }^{15}$ Ibid.

${ }^{16}$ Ibid., 6 .

${ }^{17}$ Ibid., 7.

${ }^{18}$ Ibid.

${ }^{19}$ Ibid.

${ }^{20}$ Ibid., 8 .

${ }^{21}$ Ibid.

${ }^{22}$ See Ibid., 9-29 for further details.

${ }^{23}$ Israel Charny, "A classification of denials of the Holocaust and other genocides," in The genocide studies reader, eds. Samuel Totten and Paul R. Bartrop (New York: Routledge, 2009), 519.

${ }^{24}$ Ibid., 525.

${ }^{25}$ Ibid., 526 .

${ }^{26}$ Ibid., 529 .

${ }^{27}$ Ibid., 532.
} 
The deniers associated to this category may have suffered genocide themselves or share a history of past enmity with other people or groups of people. "Human shallowness-the dulling and depletion of a genuine sense of tragedy and moral outrage" is a category that involves denials based on the desensitization, the trivialization or the routinization of genocide-related events. ${ }^{28}$

Instead of classifying different forms of denial, Lemarchand distinguishes between denial and revisionism. ${ }^{29}$ The author defines denial as the contestation that genocide occurred because of the absence of demonstrable intent to annihilate. Revisionism implies the creation of new circumstances surrounding genocidal violence and the devising of new motivations where victims often turn out to be the perpetrators and each can be found on both sides ${ }^{30}$ Lemarchand adds that denial and revisionism both entail the leaving out of some details and the manipulation of historical facts in order to portray the victims as being the aggressors and to exonerate the perpetrators. ${ }^{31}$ Hirsch contends that individuals and collectives tend to use the same strategies to block out or to silence an unbearable and horrendous memory or event: denial, the shifting of blame, rationalization and relativization. ${ }^{32}$ The author explains that the denial of facts is not so easy to contest and even necessitates counterintelligence efforts as deniers present "details as valid information." ${ }^{33}$ Hirsh adds that historical evidence does not necessarily prevail over lies and oversimplification. $^{34}$ In the case of blame shifting, the perpetrator becomes a victim by blaming others for what happened. Rationalization entails justification for the unacceptable behavior. Relativization explains the events and related immoral behavior that took place in comparison to others. Adam Jones identifies a number of denial strategies..$^{35}$ Among them we find: portraying the atrocities as self-defense, understating the scope of the massacres, stating the absence of genocidal intent, pointing out the absence of clear or direct orders, downplaying the original population's demographic weight, describing oneself and/or group as being pure and thus incapable of mass atrocities, or on the other hand, as being the real victims. ${ }^{36}$ Denial-the last stage of Gregory $\mathrm{H}$. Stanton's ten stages of genocide-occurs throughout each of the different stages and continues beyond the genocide. ${ }^{37}$ It is one of the surest predictors of future genocidal massacres. Stanton indicates that denial comprises covering up the evidence (e.g. burning the bodies, digging up the mass graves), denying their criminal deeds, blaming the victims and intimidating the witnesses. ${ }^{38}$ According to the author, arrests and prosecutions allow for the evidence to be heard and helps to combat impunity as punishment contributes to diminishing denial. ${ }^{39}$

The use of increasingly sophisticated cognitive strategies such as rationalization, contextualization, deconstruction and/or justification allows for mass killings to become a legitimate governmental response to an attack or the threat of an attack. Accordingly, the most dangerous form of denial (i.e. facilitating or reinforcing the committing of further atrocities) is interpretative denial. As previously seen, this implies the deliberate weakening of the factual foundation of genocide by mixing in elements of acknowledgement of historical facts and/or consideration for the violence and deaths suffered with lies and denials. As time passes, the tangible genocide-related facts incrementally disappear while the survivors' memories and experiences are increasingly silenced. This kind of denial is dangerous not only because it disseminates uncertainty, ambiguity and even contradiction, but also for the reason that it has permeated different spheres of society (political

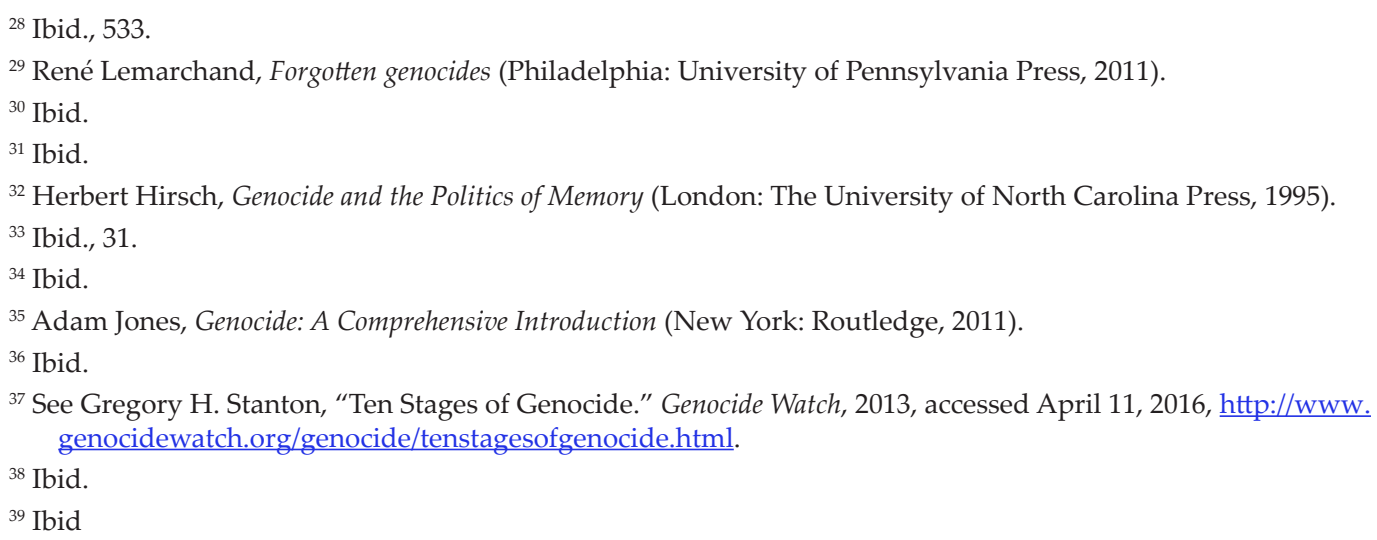


and academia) under the principle of free speech where opposing points of view ought to be heard. Interpretative denials of genocide then become tantamount to diversity of opinion and can then easily be integrated in the media, publications, public forums (lectures, conferences and so forth). A number of academics - such as David Irving-have had much success denying genocide (see Smith and al. 1995, for a few examples). ${ }^{40}$ While a few countries such as Canada and Germany have legislated that denial of the Holocaust is subject to legal prosecution, interpretative denials are more discrete and difficult to identify. Holocaust deniers have not been criminalized in most countries, including the United States, UK and $\mathrm{BiH} .{ }^{41}$ Adam Jones argued against imposing legal sanctions against deniers, opting instead for other strategies such as public refutation (proactive campaigns and denunciation informed by thorough research,) to minimize further damage from unethical denials. ${ }^{42}$ Other authors such as Smith, Markusen and Lifton stand for legal sanctions against genocide deniers. ${ }^{43}$

Denial serves to numb, enables avoidance of the unthinkable or protects the psyche by blocking out awareness of cruelty and extreme horrors committed by some towards others, especially when members of one's in-group are identified as mass murderers. However, denial also negates responsibility, revives painful and harmful memories, and further damages the victims and other individuals who are affiliated with them. Such distortions of truth and revisions of history aim to demolish the identity of the targeted group and to control people's mind constructions about the events or a number of aspects related to genocide. While no link has been established between intentions and the conscious/unconscious processes at play, perpetrators and their allies deliberately use highly sophisticated strategies to further their goals. Other than the perpetrators and their supporters, ordinary individuals are drawn to denial for different self-serving reasons such as protecting one's own position by accepting the institutional culture or to benefit from funds that will support his or her denial. Some authors such as Charny note that denials disseminated by non-perpetrators and apparently well-intentioned people (defending human rights and justice standards, for instance) are the most widespread form of denials and are especially dangerous as they are very damaging to the societal support of historical truth, justice and impartialness. ${ }^{44}$

\section{Interpretative Denial in BiH (and Beyond)}

Everything the victims say is relativized, reduced in courts, denied by the perpetrators. Any such strategy used to modify the truth further damages the victim. ${ }^{45}$

Interpretative denial, where facts or historical events are given a different meaning, is the view which is most prevalent in $\mathrm{BiH}$. This form of denial has many supporters, most notably, among political leaders (international community, Serbia, Bosnian Serbs in eastern Bosnia) and academic experts. During the 1990's, while the worst atrocities were taking place in Bosnia, political leaders avoided use of the term genocide as such acknowledgement would have required an intervention from those who had signed the Genocide Convention. ${ }^{46}$ As for Serbia, a draft resolutionrecognizing genocide-was introduced in 2005 but the Serbian Parliament did not adopt it. ${ }^{47}$ In 2010, it acknowledged that a "crime" and a "tragedy" had occurred in Srebrenica but never

\footnotetext{
${ }^{40}$ For example, see Roger W. Smith, Eric Markusen and Robert Jay Lifton, "Professional ethics and denial of the Armenian genocide," in Holocaust and Genocide Studies 9, no.1 (1995): 1-22.

${ }^{41}$ Jaqueline Lechtholtz-Zey, "The Laws Banning Holocaust Denial (revised from GPN Issue 3)," Genocide Prevention Now 9 (2012), accessed February 3, 2015, http://www.genocidepreventionnow.org/Home/GPNISSUES/ GPNBulletinLAWSAGAINSTDENIALSpecialSection9/tabid/164/ctl/DisplayArticle/mid/971/aid/470/Default.aspx.

${ }^{42}$ Adam Jones, The Scourge of Genocide (New York: Routledge, 2013).

${ }^{43}$ Smith, Markusen and Lifton, "Professional ethics and denial," 1-22.

${ }^{44}$ Charny, "A classification of denials," 525.

${ }^{45}$ Interview with woman (50-65 years old), Bosnia and Herzegovina, May 2012.

${ }^{46}$ Thomas Cushman, "Anthropology and genocide in the Balkans," Anthropological Theory 4, no.1 (2004): 5-28.

${ }^{47}$ Michel-André Horelt, "Serbia-Croatia, Bosnia and Herzegovina: Different apology packages, different successes," in Apology and Reconciliation in International Relations, ed. Christopher Daase et al. (New York: Routledge, 2016).
} 
referred to it as genocide..$^{48}$ Serbian authorities began arresting suspects of Srebrenica-related crimes in March 2015..$^{49}$ In July 2015, Aleksandar Vučić-Serbia's Prime Minister-attended the $20^{\text {th }}$ anniversary of the Srebrenica massacre, where he condemned "the crime" but did not use the term genocide.$^{50}$ Vučić - a former ultranationalist politician during the 1992-1995 Bosnian war who is currently embracing the region's efforts for joining the European Union-was attacked at the ceremony with water bottles and stones. ${ }^{51}$ Vučić had mentioned the following in the 1990's: "for every killed Serb we will kill 100 Muslims." ${ }^{52}$ Also in July 2015, Russia vetoed a UK and US-drafted UN Security Council resolution on the Srebrenica massacre of $1995 .{ }^{53}$ This resolution-meant to mark the $20^{\text {th }}$ anniversary of the Srebrenica massacre-would have formally condemned the massacre as genocide. ${ }^{54}$ Russia was the only country to veto the resolution. China, Nigeria, Angola and Venezuela abstained, while the other ten members of the Council voted in favor. ${ }^{55}$ The draft resolution failed, as a permanent member of the Security Council issued the veto. This veto only further hinders the reconciliation process in $\mathrm{BiH}^{56}$ In the Serb-dominated Republika Sprska, denial remains strong. ${ }^{57}$ The notion of "equal guilt for equal crimes," whereby the Serbs' forces were not the only bad guys has been propelled by means of political, academic and journalistic discourses by members of the international community, Serbia and Bosnian Serbs in eastern Bosnia. ${ }^{58}$ Cushman explains that this relativism, among other factors, has been fuelling both the denial of Serbian culpability for the crimes that occurred during the 1990's as well as the intensification of Serbian victimhood. ${ }^{59}$ Edina Bećirević underlines that "idea linkage distortion and time-sequence confusion" is a method of denial often used by individuals who point out genocide against Serbs during WWII to justify the atrocities carried out in $\mathrm{BiH}$ in the $1990^{\prime} \mathrm{s} .{ }^{60}$ The author adds that those who disseminate this perspective disregard, among other facts, that both Bosniaks and Croats (and others, such as Jews) were "victims of WWII-era genocidal policies" adopted by certain Serbs. ${ }^{61}$

In regards to the academic circles, Edward S. Herman-Professor Emeritus at University of Pennsylvania, a media analyst and a well-known revisionist-has repeatedly denied the genocide in BiH. ${ }^{62}$ Noam Chomsky-Professor Emeritus at the Massachusetts Institute of Technology and

${ }^{48}$ Ibid

${ }^{49}$ Jovana Gec, Aida Cerkez and Dusan Stojanovic (The Associated Press), "8 suspects arrested in Srebrenica massacre, including commander," Global News, March 18, 2015, accessed April 13, 2016, http://globalnews.ca/news/1888850/ serbian-police-make-seven-arrests-linked-to-srebrenica-massacre/.

${ }^{50}$ BBC, "Srebrenica massacre anniversary: Crowds chase Serb PM away," BBC News, July 11, 2015, accessed April 14, 2016, http://www.bbc.com/news/world-europe-33491540.

${ }^{51}$ The Associated Press, "Serbian PM attacked at ceremony marking Srebrenica slaughter," CBS News, July 11, 2015, accessed April 14, 2016, http://www.cbsnews.com/news/serbian-pm-aleksandar-vucic-attacked-at-ceremony-markingsrebrenica-slaughter-in-bosnia/.

${ }^{52}$ AFP, "Ties between Serbia and Bosnia remain fragile 20 years after war," Justice Info.net, July 11, 2015, accessed April 17, 2016, http://www.justiceinfo.net/en/live-feed/1223-.html.

${ }^{53}$ Reuters, "Russia vetoes Srebrenica genocide resolution at UN", The Guardian, July 8, 2015, accessed April 13, 2016, http:// www.theguardian.com/world/2015/jul/08/russia-vetoes-srebrenica-genocide-resolution-un.

${ }^{54}$ Denis Dzidic, "Russia Vetoes UN Srebrenica Genocide Resolution," Balkan Transitional Justice, July 8, 2015, accessed April 13, 2016, http://www.balkaninsight.com/en/article/russia-vetoes-un-srebrenica-genocide-resolution.

${ }^{55}$ Graeme Baker, "Russia criticised for vetoing UN Security Council resolution to condemn 1995 Srebrenica massacre as 'genocide'," Independent, July 8, 2015, accessed April 13, 2016, http://www.independent.co.uk/news/world/europe/ russia-criticised-for-vetoing-un-security-council-resolution-to-condemn-1995-srebrenica-massacre-as-10376244.html.

${ }^{56}$ Dzidic, "Russia Vetoes UN Srebrenica Genocide Resolution."

${ }^{57}$ Valerie Hopkins, "In the shadow of genocide," Foreign Policy, July 10, 2015, accessed April 7, 2016, http://foreignpolicy. com/2015/07/10/in-the-shadow-of-genocide-srebrenica-bosnia/.

${ }^{58}$ Bećirević, Genocide on the Drina River, 146 and 173 respectively; See also Marko A. Hoare, "Genocide in the former Yugoslavia," Journal of Genocide Research 5, no.4 (2003): 543-563; Campbell, National Deconstruction.

${ }^{59}$ Thomas Cushman, "Anthropology and genocide."

${ }^{60}$ Bećirević, Genocide on the Drina River, 173.

${ }^{61}$ For more details see Bećirević, Genocide on the Drina River, 174.

${ }^{62}$ See the following link for instance, Edward S. Herman "The Politics of the Srebrenica Massacre" Покрет за Србију (Movement for Serbia), February 23, 2008, accessed April 7, 2016, http://pokretzasrbiju.org/the-politics-of-the-srebrenicamassacre-by-edward-s-herman/. 
one of the most widely quoted intellectuals - wrote the foreword to Herman's book The Politics of Genocide which denies the genocides of Srebrenica and Rwanda. ${ }^{63}$ Diane Johnstone-an American political essayist and columnist-also wrote a book which denies the genocide of Srebrenica. ${ }^{64}$ Robert Hayden - a professor in anthropology of law and politics at the University of Pittsburghportrayed the genocidal massacres that happened in $\mathrm{BiH}$ in the 1990's as "removals." ${ }^{55}$ However, a number of well-known authors such as Marko Hoare, Samantha Power, Martin Shaw, and Gregory Stanton have highlighted the detrimental political effects and consequences of academic denial on the prevention of genocide. ${ }^{66}$

With respect to the judiciary, both the ICTY and the International Court of Justice (ICJ) have recognized that genocide did occur in $\mathrm{BiH}$, but each relativized the facts. ${ }^{67}$ For instance, in 2007, the ICJ acknowledged that Serbia had violated the Genocide Convention, by not doing enough to prevent it from occurring, and yet still decided to release the Serbian state from full responsibility. ${ }^{68}$ As for the ICTY, through its settlements with war criminals offering the latter shorter sentences for confessions, it also contributed to the relativization of the mass atrocities committed in the $1990^{\prime} \mathrm{s} .{ }^{69}$ Most of the interviewees who participated in the current study were of the opinion that a significant amount of information was revealed through judicial courts such as the ICJ, the ICTY and the War Crimes Chamber (of the State Court of Bosnia and Herzegovina). However, they deplored the manipulation of information that seeks to minimize, rationalize, justify, deconstruct and/or deny the violent deeds perpetrated as well as their consequences. Nettelfield indicates that, despite criticism from a number of scholars such as Stover and Weinstein and Subotić, the ICTY led to a number of positive developments by enabling the creation of a space for exchanges, questions and discussions concerning the mass atrocities committed in the 1990 's. ${ }^{70}$ Among the positive impacts highlighted by Nettlefield, we find initiatives aimed at: informing and educating the population, working on decreasing collective guilt, helping in the legitimization of the survivors and family associations, locating war criminals and developing local capacity to prosecute war crimes in $\mathrm{BiH} .{ }^{71}$ Over the years, a few reports have exposed a number of problems linked to interference by the executive and legislative bodies (as well as by political leaders), in the workings of the judiciary, resulting in lengthy court proceedings and often impunity for the perpetrators. ${ }^{72}$

Denial is pervasive throughout Serbia and Serb-dominated Republika Sprska. This denial is also supported and reinforced by members of the international community from diverse spheres (political, academic, media, law). However, as explained by Charny, personal interests - tangible and non-tangible-drive many individuals who were not initially perpetrators nor bigots to deny and even participate in massacres and genocide. ${ }^{73}$ Despite the ambiguity and the grey zones in terms of intentions and the purposes for denial of genocide, the latter has a profound negative impact on everyone concerned, especially the victims and their children. The denial of genocide goes beyond the manipulation, contradiction and/or rebuttal of historical facts, it recreates the conditions under which the victims' extreme suffering is perpetuated and further victimization is made possible, yet again.

\footnotetext{
${ }^{63}$ Edward S. Herman and David Peterson, The Politics of Genocide (New York: Monthly Review Press, 2011).

${ }^{64}$ Diana Johnstone, Fools' Crusade: Yugoslavia, NATO and Western Delusions (London: Pluto Press, 2002).

${ }^{65}$ Robert Hayden, “The tactical uses of passion in Bosnia," Current Anthropology 38, (1997): 924-926. See also Thomas Cushman, "On Bosnia: Response to Hayden," Current Anthropology 40, no.3 (1999): 365-366.

${ }^{66}$ Bećirević, Genocide on the Drina River.

${ }^{67}$ Ibid.

${ }^{68}$ Ibid.

${ }^{69}$ Ibid.

${ }^{70}$ Nettelfield, Courting Democracy in Bosnia and Herzegovina.

${ }^{71}$ Ibid.

${ }^{72}$ See for instance, JNBiH, Joint Report of the Justice Network in Bosnia and Herzegovina for the 2nd Universal Periodic Review on Human Rights Situation in Bosnia and Herzegovina (Sarajevo, 2014), accessed April 11, 2016, http://www.mrezapravde. $\mathrm{ba} / \mathrm{mpbh} / \mathrm{mpbh}$ files/file/UPPreportFinalENG.pdf.

${ }^{73}$ Charny, "A classification of denials," 519.
} 


\section{The Effects of Denial in BiH at the Individual, Group and Societal Levels}

In some cases, certain forms of denial can be considered as being potentially beneficial. The avoidance of situations that are reminders of trauma can constitute a practical coping mechanism. As explained by Joseph, William and Yule, this avoidance allows for an incremental process where facilitation and inhibition processes modulate and maintain the flow of traumatic information at tolerable doses.$^{74} \mathrm{~A}$ (psychological) space where survivors are able to regulate and handle their experiences - cognitively, emotionally and behaviorally - is needed to allow for the development of the ability to move on. Overwhelming circumstances, where individuals face ongoing psychological invasions, provide few opportunities for (re)connecting with oneself, others and life in general. For instance, a person may have difficulties experiencing painful and enjoyable thoughts simultaneously, or feelings of distress and love or kindness. Psychological invasions or intrusions concern past as well as future-oriented events, especially for those who still live in the areas of conflicts. Wondering if oneself and his or her children will be accepted as equal citizens on account of his or her background is an example of a future-oriented event.

The denial referred to by the interviewees is a form that triggers new and/or perpetuates past trauma-related responses. As one feels or believes that he or she is in danger-psychologically and/or physically - traumatization increases. Repeated or continuous ordeals such as stressors inflicted with intent produce varying degrees of detrimental effects on both mental and physical health. Effects such as emotional numbness, anxiety, helplessness, frustration, anger, deep sadness, fear and somatisation are the most often mentioned by the interviewees. Symptoms that seem to fade away over time resurface again in response to other stressful situations. When this occurs repeatedly and over prolonged periods of a person's life, the impacts are felt through one's perceptions of negative stimulus, negative cognitions and negative emotions, which in turn influence behavior towards out-group members. ${ }^{75}$

Drawing from the interviewees' statements, denial is interpreted as an intrusion of the past into the present in which the individual is confronted to an account of violent events that does not correspond to (or contradicts) his or her own experience. Denial triggers repeated recollection of past traumatic events, rather than living in the present and contemplating a future. As noted by Charny, the survivors' history, rationality and truth are negated. ${ }^{76}$ Denial effectively celebrates the past devastations experienced by victims as they are submitted to a falsified version of their own experience and history. ${ }^{77}$ Denial reaffirms ongoing indifference, dehumanization, hostility and aggression. As we will see, denial also obstructs and/or ends dialogue that ought to take place for the healing process to occur and to help prevent further traumatisation at both individual and collective levels. Most of the interviewees reported being significantly to severely affected by denial. The younger ones-between 18 and 25 years old-reported being more disturbed by their parents' reactions and related daily problems (physical, psychological, economic, social). Four themes emerged from the interviews regarding the consequences or outcomes of denial at the individual level: 1) irritability, frustration and anger;2) depressive symptoms;3) anxiety symptoms; 4) survivor guilt. According to Hutchison, heed ought to be paid to the consequences experienced by the victims as they engender homologous responses i.e. extend beyond and between individual persons. ${ }^{78}$ At the group level, two themes were found: mistrust and fear.

\footnotetext{
${ }^{74}$ Stephen Joseph, Ruth Willliam and William Yule, Understanding post-traumatic stress (New York: Wiley, 1997).

${ }^{75}$ Miles Hewstone et al. "Why neighbours kill: Prior intergroup contact and killing of ethnic outgroup neighbours," in Explaining the breakdown of ethnic relations: Why neighbours kill, eds. Victoria M. Esses and Richard A. Vernon (Malden: Blackwell Publishing, 2008).

${ }^{76}$ Israel Charny, "The psychology of denial," Genocide and human rights. A special issue of the journal of Armenian studies IV (1E2) (2009): 289-306.

${ }^{77}$ Ibid.

${ }^{78}$ See Emma Hutchison, Affective communities in world politics: Collective emotions after trauma (Cambridge: Cambridge University Press, 2016).
} 
Irritability, Frustration and Anger

Anger is attributed to the feeling that something bad, wrong or unjust, has occurred. ${ }^{79}$ The denial of extreme atrocities such as the ones which were perpetrated in $\mathrm{BiH}$, and the resulting consequences, is considered by the interviewees as being deeply immoral and criminal. Different forms and levels of anger were expressed by all the interviewees. The survivors' level of anger was essentially influenced by: the perpetrators' denial of responsibility for what happened and/ or denial of the victims' sufferings; the absence of punishment or negative consequences for the perpetrators; the lack of acknowledgement of the perpetrators' immoral deeds and the reinterpretation of past transgressions as being heroic. Also, most interviewees were explicit about feeling anger (or another level of anger) towards the perpetrators (versus the ethnic group as a whole). The following interviewees expressed anger in response to the perpetrators' refusal to recognize the crimes committed and the losses suffered.

It is very frustrating to see them perpetually lying like that and not recognizing what they have done. This makes me extremely angry, every time I hear their lies. I don't know what to say. ${ }^{80}$

Who killed my husband and my two sons? I can't even go back and live in Srebrenica anymore.

I am beyond angry that Serbs are denying the genocide they perpetrated in Srebrenica! ${ }^{81}$

Similarly, Kalayjian et al's research indicates that the persistent Turkish denial of the 1915 Armenian genocide induced feelings of intense anger in many survivors. ${ }^{82}$ In regards to the current study, the lack or the absence of acknowledgement on the part of the perpetrators further fuels the interviewees' feelings of powerlessness and profound sense of injustice regarding their past and present daily circumstances. Some internalize their anger while others displace it onto their family members, peers, acquaintances or unknown individuals. In this respect, Mira Giberovitch indicates that the survivors' victimization continues when they are allowed to project their anger towards other individuals. ${ }^{83}$ Many interviewees expressed concerns regarding the effects of their anger on their own children and families, even those who internalized their anger. Some interviewees pointed out that they preferred isolating themselves rather than hurting their loved ones, especially their children.

\section{Depressive and Traumatic Symptoms}

Herman highlights that the presence of enduring depressive symptoms is the most common finding in studies on traumatized individuals. ${ }^{84}$ She also adds, "every aspect of the experience of prolonged trauma works to aggravate depressive symptoms." ${ }^{85}$ Most of the interviewees spontaneously shared that they are still afflicted, to varying degrees, by their war-related physical and/or psychological sufferings. Little remains from the survivors' pre-war existence. For too many, their families have been partially or completely decimated, friends and peers have been murdered. Moreover, many were left with little or no opportunity to bury and mourn their deceased loved ones. Their homes have been destroyed or taken, educational institutions and livelihood opportunities have been destroyed, and whole communities have been dismantled. Minorities have been strongly discouraged from returning to their homes as well. Many interviewees highlighted that their sense of loss and their pain was so great that it was difficult for them to express. Denial contributes to the survivors' irrecoverable losses and this is further compounded by the lack of assistance and

\footnotetext{
${ }^{79}$ Ibid.

${ }^{80}$ Interview with woman (20-25 years old), Bosnia and Herzegovina, June 2014.

${ }^{81}$ Interview with woman (55-65 years old), Bosnia and Herzegovina, June 2014.

${ }^{82}$ Anie S. Kalayjian, Siroon P. Shahinian, Edmund L. Gergerian, “Coping with Ottoman Turkish Genocide," Journal of Traumatic Stress 9, no. 1 (1996): 87-97.

${ }^{83}$ Myra Giberovitch, "A drop-in center for holocaust survivors: Inspiring hope, meaning, and purpose," Journal of Jewish Communal Service 75, no. 3-4 (2006): 239-247.

${ }^{84}$ Judith Herman, Trauma and recovery (New York: Basic Books, 1997).

${ }^{85}$ Ibid.
} 
support. Drawing from the interviewees' accounts, the intensity of these symptoms appears to be affected by three main factors: the loss of loved ones (children, partner, parents, siblings and relatives), the magnitude of the losses endured, the ability of the perpetrators to carry on with their lives without experiencing any apparent negative consequences for their violent behavior. Many interviewees also emphasized that not being informed of the location of the body of missing loved ones considerably increases their pain and suffering. The younger interviewees were saddened and troubled by their parents' grief and misery. The following testimonies reveal that the denial of the facts surrounding the genocidal events which resulted in their loved ones being killed was equivalent to reliving the ordeal, compounded by the knowledge that the very existence of their loved ones was being erased. This form of denial is tremendously damaging to the interviewees and prolongs the mourning process as the mourner feels obligated to cling to the person lost. ${ }^{86}$

Their denials revive the memories of the ones that we loved again... My husband was everything to me. It is as if my husband never existed. The mourning process keeps on occurring. ${ }^{87}$

They killed my son and they live as if they did nothing and nothing happened. Nothing in the world can bring me happiness or pleasure. Deep inside, I am unable to be happy. ${ }^{88}$

The survivors struggle on a daily basis in coping with inestimable hardships. Denial not only perpetuates their victimization but also devalues their existence before, during and after the 1990's war. Kellerman observed that severely depressed (Holocaust) survivors were at a high risk for suicidal thoughts and attempts. ${ }^{89}$ Denial even led some of the interviewees to wonder why they had survived.

\section{Anxiety Symptoms}

The denial of genocide-related events and their consequences provides a clear indication to most of the interviewees that if similar circumstances to those leading to genocide were to occur again, nothing would be done to stop the process. Most interviewees spontaneously mentioned a persistent subjective and/or objective psychological and physical insecurity linked to the threat of the reoccurrence of similar events. Such threats may be perceived as being very real for the survivor. As the survivors relive a threatening and frightening past, traumatic symptoms are triggered and resurface again in response to traumatic stressors. The older interviewees who directly experienced war as adolescents or as adults often expressed the most intense feelings of insecurity. The younger interviewees shared feeling anxious when their loved ones experienced symptoms like anxiety and/or fear. These interviewees underline that the denial of their experience puts them back in their painful memories, stimulates traumatic symptoms, and feeds the thought that these atrocities could occur again. Indeed, as raised by one of the following interviewees, the absence of accountability and the justification for the crimes perpetrated increases the likelihood of their reoccurrence.

Their denials and lies make me relive what happened all the time. Everything comes back, the jumpiness, the nightmares... but worse... the trauma, everything. ${ }^{90}$

We were targeted by snipers for four years... always running to avoid being killed. I am still traumatized, always nervous. Serbs justify the bombings, deny the snipers... It makes me even more nervous to see that there is no accountability from their part. ${ }^{91}$

\footnotetext{
${ }^{86}$ Brandon Hamber, Transforming societies after political violence (New York: Springer, 2010).

${ }^{87}$ Interview with woman (45-55 years old), Bosnia and Herzegovina, July 2014.

${ }^{88}$ Interview with woman (55-65 years old), Bosnia and Herzegovina, June 2013.

${ }^{89}$ Nathan P. E. Kellerman, Holocaust trauma: Psychological effects and treatment (New York: iUniverse, 2009).

${ }^{90}$ Interview with man (40-50 years old), Bosnia and Herzegovina, June 2014.

${ }^{91}$ Interview with woman survivor (35-45 years old), Sarajevo's siege, April 2011.
} 
Two factors which significantly contribute to the survivors' symptoms of anxiety are: $\mathrm{BiH}^{\prime} \mathrm{s}$ ongoing socio-economic problems and the ethno-nationalistic political leaders' inflammatory narratives which serve to revive traumatic memories from the 1990s. Emma Hutchison indicates that discourses of fear, anxiety and other similar emotions maintain and reinforce the power of a nation-state by promoting inside/outside dichotomies and antagonistic political allegiances as responses to keep the perceived dangers at bay. ${ }^{92}$ Increasing the intergroup distance diminishes the likelihood of a very much-needed intergroup dialogue that would diminish individual and collective anxiety symptoms.

\section{Survivor Guilt: Bearing Witness and Remembering Those Who Perished}

Survivor guilt does not exclusively refer to feelings often experienced by those who survived lifethreatening events in which many others, especially their loved ones, perished. One's perception that he or she did not do enough to save those who died and one's feelings of being unworthy relative to those who perished are among the most frequent sources of survivor guilt. One may be prompted to bear witness and to keep alive the painful memory of those who were killed. All the interviewees who participated in this study indicated that they were significantly affected by the Serbs' denial of genocide. They felt a strong obligation, placed upon them directly or indirectly, to be the bearers of the hopes of their family and/or of the Bosnian people. It was mentioned by a few that the survivor's children grew up with a sense that because of this past and the sufferings of their parents, they ought to be successful (academically or in terms of employment) so as to bring about change that will lead to peace. However, the gap between the survivors' expectations and/or hopes, and what their children perceive as being feasible is significant. The current challenging socio-political situation within $\mathrm{BiH}$ contributes to increasing the next generation's difficulties in fulfilling these aspirations. ${ }^{93}$ The following testimony underlines the pressure felt by the younger generation to succeed in different spheres of their lives in a way that would compensate for the absence of acknowledgement for the extreme losses incurred. The younger interviewees underscore the pressure to bring about changes that are very much needed at both meso and micro levels of $\mathrm{BiH}$. However, as noted by this interviewee, there are little to no opportunities, nor perceived possibilities, for the younger generations to satisfy these expectations.

I definitely feel that I have to succeed with every aspect of my life in order not to disappoint them (parents)... There is no acknowledgement of our losses from their part (Serbs) so I feel I ought to compensate to make things better. This is stressful because I cannot find a job right now. The situation is bad for all of us. We want to do well, we get diplomas but there are no jobs, no opportunities for us. The economic situation is very difficult in BosniaHerzegovina. ${ }^{94}$

Moreover, most of the younger interviewees often felt that they had to be mindful not to agitate their parent(s) for fear of triggering yet another episode of anger, anguish, anxiety or guilt. A vast body of literature indicates that a traumatized survivor's behavior can be significantly impaired by his or her posttraumatic symptoms. ${ }^{95} \mathrm{~A}$ few interviewees shared their difficulties with emotional expression and intimacy, even with their partner and their children. Feelings of detachment, the incapacity to express emotions, numbness, irritability and nervousness are among the most frequently mentioned problems. Lauterbach et al. point out that the survivors' traumatic symptoms

\footnotetext{
${ }^{92}$ Hutchison, Affective communities in world politics.

${ }^{93}$ Millennium Development Goals Achievement Fund (MDG-F), Voices of youth: Survey on youth in BiH (MDG Achievement Fund: Sarajevo, 2012), accessed April 15, 2016, http://www.ba.undp.org/content/bosnia and herzegovina/en/home/ library/democratic governance/voices-of-youth.html.

${ }^{94}$ Interview with man (20-25 years old), Bosnia and Herzegovina, June 2014.

${ }^{95}$ See for instance Fawziyah A. Al-Turkait and Jude U. Ohaeri, "Psychopathological status, behavior problems, and family adjustment of Kuwaiti children whose fathers were involved in the first gulf war," Child and adolescent psychiatry and mental health 2, no.1 (2008), 12.
} 
such as numbness and avoidance affect their children who grow up in an environment lacking in intimacy and emotional expression. ${ }^{96}$

Drawing from the interviewees' experience, in concurrence with literature in health psychology, traumatisation does not exclusively trigger psychological symptoms. A positive correlation is found between prior trauma and physical problems such as increased risk of cancer, vulnerability to infections and immunologic disorders, susceptibility to hypertension and atherosclerotic heart disease, as well as cardiovascular, neurological, pulmonary and gastrointestinal problems. ${ }^{97}$

At the group level, increased mistrust and fear were among the most prevalent emotions associated with denial from the perspective of the interviewees. Both emotions intensify intergroup distance and tensions.

Mistrust

Renewed trauma brought on by denial contributes to the erosion of social ties and the breakdown of trust as well as social polarization between individuals, communities and groups. Ultimately those belonging to out-groups become the negative other. Agger ${ }^{98}$ contends that the loss of trust in humankind following the betrayal of one's neighbour or one's family member constitutes the most traumatic and pervasive experience for war survivors to cope with. The following interviewees question how the perpetrators can be trusted again and allowed to be reintegrated in society when they do not take responsibility for the crimes they committed. How can trust be (re)built in such circumstances and/ or when atrocities are celebrated by the other group?

It's unimaginable! Parents have to live without their children, women without their husbands. Raped and tortured women are physically and psychologically damaged. Too many were killed, tortured, humiliated, molested and because of that, their future is ruined. How can one live a normal life after committing such deeds... and without punishment? How can we trust someone like that who does not admit and take responsibility? Someone who feels no shame for what he has done and who is even seen as a hero by his people? They were even rewarded for it!99

Trust cannot happen without truth. Criminals need to admit what they did to begin healing. It will happen again if they do not heal. ${ }^{100}$

Fear

Without exception, the interviewees mentioned that denial of what happened to them intensified their perception of being threatened, fuelled their fear of the other and amplified their sense of uncertainty regarding what the future holds for them. Stephan, Renfro and Davis indicate that threat perception arouses the emotion of fear. ${ }^{101}$ Fear of certain groups can become chronic and well integrated into the in-group's history; and eventually transforms an ethnic conflict into an intractable war. Drawing from the interviews, we found that the effects of threats experienced (or perceived) may be psychological or behavioral in nature. The psychological consequences comprise cognitive (e.g. stereotypes) and emotional reactions (e.g. fear, anger). An important consequence of fear which affects intergroup relations is that fear focuses on threatening stimulus

\footnotetext{
${ }^{96}$ Dean Lauterbach et al. "Quality of parental relationships among persons with a lifetime history of posttraumatic stress disorder," Journal of traumatic stress 20, no. 2 (2007): 161-172.

${ }^{97}$ See for instance Joseph A. Boscarino, "Posttraumatic stress disorder and physical illness: Result from clinical and epidemiologic studies," Annals of the New York Academy of sciences 1032 (2004): 141-153.

${ }^{98}$ Inger Agger, "Reducing trauma during ethno-political conflict," in Peace, Conflict, and Violence, eds. Daniel J. Christie et al, (Englewood Cliffs: Prentice-Hall, 2001): 240-250.

${ }^{99}$ Interview with man (40-50 years old), Sarajevo's siege, June 2013.

${ }^{100}$ Interview with woman (45-55 years old), Bosnia and Herzegovina, June 2014.

${ }^{101}$ Walter G. Stephan, Lausanne C. Renfro and Mark Davis, “The role of threat in intergroup relations," in Improving intergroup Relations: Building on the legacy of Thomas F. Pettigrew, eds. Ulrich Wagner et al. (Malden: Blackwell Publishing, 2008): 55-73.
} 
and controls information processing where danger is increased and information (or events) are perceived and interpreted as being negative or threatening. Negative events and information attract more attention, are more readily memorized and thus more intensely affect perceptions, interpretations and behaviors of the antagonistic groups. Then, the fear becomes justified by an enhanced perception of danger posed by the out-group.

Fear impacts intergroup dynamics as well through increased group cohesiveness, increased acceptance of centralized leadership, and exclusion of non-conforming/deviant members. Intense fear associated with enhanced group cohesiveness breeds hostility toward the outgroup. Avoidance of the out-group is another possible consequence of fear. Furthermore, the combination of fear and the negative characteristics of the out-group reinforces avoidance of intergroup contact. Among other reasons for this avoidance, we find the expectation that the interaction will go poorly or that negative outcomes will be experienced. Examples of such possible negative outcomes during intergroup interaction include: condemnation from outgroup and/or in-group as well as being exploited or harmed (physically and/or psychologically). Under certain circumstances, fear influences the perceptions of threat from a hostile out-group, laying the foundation for defensive aggression. Denial intensifies perceptions of threat. The interviewees deplore the lack of recognition on the part of the perpetrators. They fear that, without such recognition, nothing will prevent the perpetrators from acting (again) with extreme violence in the future.

We are in need of not being afraid of the other. I do not see this as being possible after what they have done to us. They don't even recognize their responsibility in what they did. What will be their next move? ${ }^{102}$

\section{Societal Level}

At the societal level, the nationalistic discourse and fear of the other are notions, which are promoted throughout according to most of the interviewees. The political discourse-fear mongering along nationalistic lines - and its influence on the collective memories that reign in $\mathrm{BiH}$ pinpoint and dictate who the enemy is and what he or she did, meanwhile disregarding how members of each group were affected by the war. Given the fact that traumatic memories are emotionally overwhelming and involve extreme violence, it is easy to understand why fear-mongering is so effective, even more so when considering the enduring harsh living conditions.

The remembrance of war involves multiple layers of interaction and negotiation between the representatives of the state apparatus, the political elites and the non-elites i.e. the ordinary citizens. The participating parties do not carry equal weight in the determination of who did what, what happened during the war, and what these violent actions led to. Such determination depends on who is allowed to have a voice in the public sphere. All too often, a united front of political, military and bureaucratic elites devises a unilateral memory of the war that is untouchable. The official war narratives are then sustained through the selective referencing of individual testimonies and different types of documentation (audio-visual, written). Essentially, this is the extent of individual participation in the articulation of the collective memories of war. However, some individuals or groups who claim to know the truth are not allowed to have a voice in the public sphere, especially when their truth does not coincide with the official accounts of war. Allowance for a certain degree of deviation in the accounts related to war depends on numerous variables such as the degree of defensiveness and enemy-sensitivity in the dominant political culture. War-related narratives and war memories are repeated and reinforced by telling and listening. They are rendered tangible by war museums and documentation. Once these are well established, experiences that cannot be placed in the interpretative framework of these accounts are usually left out. The more individuals with divergent memories of what happened stay silent and conform to the official version, the less likely it becomes for these variations to be included in the collective memories of war. This, in turn, significantly reduces the possibility of mourning and for an impartial acceptance of the

${ }^{102}$ Interview with man (45-55 years old), Bosnia and Herzegovina, June 2013. 
consequences of the war. Remembrance of war must be made to overcome the selective presentation and political sanitization of the memories of war. Otherwise a pseudo-healing takes places and prevents society from confronting the underlying problems which contributed to or emerged from the war.

\section{Acknowledgement in $\mathrm{BiH}$}

The Significance of Acknowledgement

Clark argues that acknowledgement implies: 1) no denial nor minimization of war crimes, 2) an absence of competing versions of truth, 3) an agreement on how the past should be dealt with. ${ }^{103}$ Čehajić-Clancy et al. indicate that acknowledgement first involves the recognition of the victims' victimization. ${ }^{104}$ Secondly, it implies the acknowledgement of responsibility for one's participation. This, in turn, implies reparations that range from public apology and memorials to financial compensation. ${ }^{105}$

The interviewees who participated in this study consider that acknowledgement involves a "genuine" recognition of the crimes perpetrated and of the losses incurred. They underlined that a genuine acknowledgement must be inclusive and respect the proportionality of suffering as some victims (and groups) suffered more than others. They all asserted that the perpetrators ought to take responsibility for their misdeeds. Many insisted that punishment was necessary, as impunity would lay the groundwork for the reoccurrence of mass atrocities.

Crimes happened on all sides but these are not equal. One side suffered the most and this ought to be recognized. ${ }^{106}$

Based on the survivors' accounts, acknowledgement serves a number of beneficial functions. First, acknowledgement lays the groundwork for a coherent narrative regarding the causes, actions and consequences of war i.e. the why, the how and the then what of war. Acknowledgement of the suffering and deprivation experienced is especially significant for the victims (to help facilitate the locating of their deceased loved ones and to obtain the relevant services for their own healing). Secondly, acknowledgement qualifies and/or justifies who is the victim and who is the perpetrator and/or labels the opposing sides. Acknowledgement of responsibility is especially meaningful for victims (as a way to ensure that those responsible will not commit similar crimes again). Overall, acknowledgement constitutes one of the main pillars of a sustainable and long-term peace in cases where severe human rights violations have occurred. However, despite the widely recognized importance of acknowledgement, there is currently a lack of empirical evidence indicating which processes and conditions best facilitate the psychological readiness to publicly and sincerely acknowledge in-group responsibility for violent past actions in intergroup conflict settings.

Finding Different Forms of Acknowledgement in BiH

As pointed out by this interviewee, whatever the form of acknowledgement, it should exclude cognitive strategies such as rationalization, contextualization, deconstruction and/or justification. Acknowledgement should not further harm the victims; rather it should allow the survivors to recover - to the extent possible-a certain level of normalcy.

Based on the interviews, the possible opportunities for acknowledgement are numerous but are seldom actually encountered in $\mathrm{BiH}$. Among those opportunities we find: the criminal trials, the commemorations and memorials on each side and against each other, and an education system that disseminates different "truths" to each group. Very few of the interviewees benefited from the monetary compensation (for raped women or other victims) but many more reported the need to address more significant and urgent problems such as the lack of

\footnotetext{
${ }^{103}$ Janine N. Clark, "From negative to positive peace," Journal of Human Rights 8, no.4 (2009): 360-384.

${ }^{104}$ Sabina Čehajić et al. "Affirmation, Acknowledgment of Ingroup Responsibility, Group-based Guilt, and Support for Reparative Measures," Journal of Personality and Social Psychology 101, no.2 (2011): 256-270.

${ }^{105} \mathrm{Ibid}$.

${ }^{106}$ Interview with man (30-40 years old), Bosnia and Herzegovina, June 2012.
} 
health care and social services. The perpetrators' acknowledgement was identified as being of utmost importance. Most also specified that making amends for one's crimes or misdeeds was equally important. This could take many forms, ranging from a simple but genuine apology to tangible actions aimed at alleviating the victims' losses. Such an acknowledgement would presuppose the disqualification of those leaders who were implicated in the 1990's killings and who are still in government and continue to be involved in the decision-making process. More importantly, the interviewees felt that the victims' suffering and losses ought to be acknowledged. As previously mentioned, the interviewees were of the view that such an acknowledgement should also help make possible the introduction of much needed healthcare and social support services. It is hoped that such assistance would ultimately facilitate the survivors' efforts at progressively reintegrating a functional life (to the extent possible). According to those interviewed, a more substantial compensation would further improve the victims' quality of life, especially for those unable to find and/or keep a job due to their posttraumatic symptoms.

Acknowledgement of what happened and the prevention of future occurrences of genocide was indicated by all the interviewees as being critical to the long term healing process. This acknowledgment was described in two forms: 1) inclusive memorials (acknowledging the disproportionate level and nature of suffering experienced); 2) education / dissemination of an inclusive and common "truth." The parallel differentiated education of each ethnic group under one roof, a practice which still exists today (despite a number of initiatives to curb such a system), was deplored by all. Finally, the interviewees added that preventing future occurrences of violence has become imperative and urgent.

\section{Considering the Threshold Between Acknowledgement and Denial}

We just want to live a normal life but I do not see how this can happen without the perpetrators acknowledging what they did. It can only mean that they think what they did is moral and they will not hesitate to do it again. A criminal cannot change. ${ }^{107}$

Living in pain, misery and fear does not help lay the foundation for positive contacts between former enemies. Fear of the other needs to decrease and a basic trust needs to be (re)built in order to move beyond the "no war no peace situation." 108 The survivors interviewed in this study also pointed out that for reconciliation to occur, the victim ought to be satisfied and reassured that the perpetrator and his accomplices acknowledge their misdeeds, the sufferings they have caused and that measures will be adopted to prevent the reoccurrence of such behavior. However, the belief in the notion that one's in-group suffering is much more important than that of the out-group's serves to minimize the in-group's sense of responsibility in the conflict. The interviewees noted that the perpetrators' admissions of guilt and/or the expression of feelings of remorse are unlikely to occur. It has been widely recognized in the literature that acknowledgement-of what happened and of one's suffering - is a crucial part of the reconciliation process. ${ }^{109}$ The different interpretations regarding what happened and the resulting consequences of war, who are to be labelled as the victims and who as the perpetrators, constitutes one of the most significant obstacles against any successful efforts of reconciliation and long-term peace. The interviewees also echoed the notion advanced by Fletcher and Weinstein, in which acknowledgement of the "truth" is not as significant as each party's interpretation and subsequent actions. ${ }^{110}$ Survivors often give more importance to the confirmation of their experience as victims and that of their loved ones-deceased or disappeared - than for learning the truth, per se.

\footnotetext{
${ }^{107}$ Interview with man (35-45 years old), Bosnia and Herzegovina, June 2013.

${ }^{108}$ An expression often use by many of the interviewees.

${ }^{109}$ For instance, see Paula Green, "Reconciliation and forgiveness in divided societies: A path of courage, compassion, commitment," in Forgiveness and Reconciliation, eds. Anie Kalayjian and Raymond F. Paloutzian (Santa Barbara: Springer, 2009).

${ }^{110}$ Laurel E. Fletcher and Harvey M. Weinstein, Violence and Social Repair: Rethinking the contribution of justice to reconciliation, Human Right Quaterly 24, no. 3 (2002), 589.
} 
Most of the interviewees felt that a balanced approach, where a certain amount of denial (or the suppression of a certain amount of information), seemed necessary for positive intergroup contacts to occur. More specifically, reconciliation required integrating an undetermined degree of denial: in terms of what happened (notably the perpetrators' violence), the losses encountered and the suffering endured. A threshold between acknowledgement and denial-a good enough amount of acknowledgement-is required before a certain degree of denial could be tolerated. When asked, a few interviewees explained that a good enough amount of acknowledgement implied: accountability of the perpetrator for his or her misdeeds, acknowledgement of the magnitude of suffering and losses, and the making of amends. However, a level of tolerable denial was more difficult to define for the victims. Most urged that at the very least, a tolerable denial must encompass: the acknowledgement of the victims' status i.e. their suffering and losses, and the accountability of the perpetrator for his or her harmful actions. The interviewees were of the view that the victims' survival needs ought to be met and that the perpetrators must be held accountable for their crimes as leniency may lead to a recurrence of the violence under similar circumstances. A vast body of literature in criminology indicates that the perpetrator's accountability is crucial for his or her own healing. ${ }^{111}$ The lower the level of denial perceived by the victims, the higher the chances a reconciliation process might occur. Drawing from the interviewees' experiences and in concurrence with the needs-based model of reconciliation, the reintegration of both the victim (taking control of their lives) and the perpetrator (being viewed as being morally and socially acceptable) is imperative. ${ }^{112}$

The healing, of all parties implicated, ought to be promoted in order to minimize objective and subjective victimization. Without the healing of each former adversary, the balance between a tolerable denial and a good enough acknowledgement cannot happen. Healing will not only decrease the tendency to interpret facts exclusively from one's point of view and dehumanize the other, it will also reduce the need to benefit from denial which, as previously mentioned, has numerous conscious and/or unconscious purposes. Herman contends that healing is a process that involves the reconstruction of the traumatic memory in order to reintegrate it into day-to-day life. ${ }^{113}$ As explained by the author, the traumatic memory is static and wordless and the survivor's endeavor in confronting and uncovering problematic questions such as what happened and why is key. Indeed, for the healing process to occur, the survivor's memory needs to be transformed into dynamic words through an individual and social reconstruction of the traumatic event. ${ }^{114}$ As discussed elsewhere, a better understanding of events entails multiple interpretations that connect the individual experience to a larger context while avoiding one-sided interpretations that emphasize the negative dispositions of the individuals belonging to the other group. ${ }^{115}$ The reconstruction of events leads to an understanding that brings forward factors that are changeable and which suggest possibilities of transformation and peace, rather than determining fixed factors such as the nature of the other that suggests the impossibility of reconciliation and peace. However, heed must be paid to prevent the manipulative insertion of justifications, rationalizations and minimizations as this would harm the victims and further slow down or impede the healing and reconciliation processes. In the context of such harmful practices, severe trauma may worsen and become entrenched. This may breed future violence and conflict.

Positive contacts allow for flexibility in looking at things from different points of view and helps in reducing the tendency to interpret events or facts exclusively from one's own perspective. Čehajić and Brown argue that a shift toward acknowledgement is more significantly correlated to the establishment of positive contacts than: the ability to adopt the perspective of the other, or

\footnotetext{
${ }^{111}$ See James Bonta, Suzanne Wallace-Capretta and Jennifer Rooney, Restorative justice: An evaluation of the restorative resolutions project (Ottawa: Solicitor General Canada, 1998).

${ }^{112}$ Arie Nadler and Nurit Shnabel, "Instrumental and socioemotional paths to intergroup reconciliation and the needsbased model of socioemotional reconciliation," in Social Psychology of Intergroup Reconciliation: From Violent Conflict to Peaceful Co-Existence, eds. Arie Nadler et al., (New York: Oxford University Press, 2008) 37-57.

${ }^{113}$ Judith Herman, Trauma and Recovery (New York: Basic Books, 1997).

${ }^{114}$ Ibid.

${ }^{115}$ Anonymous.
} 
beliefs in in-group victimhood, or a form of relationship with the adversary group where neither time nor trust has been invested. ${ }^{116}$ The authors explain that meaningful cross-group relationships with members of the victims' group contributes to increased exposure to victims' perspectives and experiences, and facilitates acknowledgement of responsibility for in-group wrongdoings. In $\mathrm{BiH}$, there must be vigilance against the political leaders' nationalistic narratives, which not only retraumatize the survivors, but also contribute significantly to an absence of the much-needed communication between stakeholders at the micro, meso and macro levels. Opening up the possibilities of dialogue as well as the space necessary for positive contacts to occur between (ex) antagonist parties has become imperative.

\section{Conclusion}

Denial is a concept which is fluid. It implies conscious and unconscious processes for both wellintentioned and non well-intentioned individuals. This fluidity also complicates its detection as well as its effects on micro, meso and macro levels. No fixed links have been established between conscious/ unconscious processes and intentions. The ambiguity and the grey areas in terms of the intentions and purposes for the denial of genocide represent a significant challenge for those who seek to counter it. Indeed, a deep understanding of the diverse incarnations of denial is necessary if one is to counter its effects by offering more effective initiatives that can be crafted and deployed against the deniers.

A meaningful and sustainable peace process implies an impartial and unbiased view of the past, the present and the future. The past has to be dealt with before one can benefit from the present to its fullest extent and (re)build in preparation of a more peaceful future. When one's suffering intensifies under the influence of "old" and "new" stressors, one is left with precious little resources to deal with his or her own daily battles and even less to (re)construct or transform one's environment and society. Denial prevents the survivors from moving on as he or she is repeatedly thrown back into the past where they relive and attempt to sort out what happened, why, how, and the then what. Having been repeatedly subjected to a falsified version of one's own experience and history, he or she is retraumatized and this incrementally shapes one's perception of negative stimulus, negative cognitions and negative emotions as well as influences the behavior towards out-group members. In the long run, each victimization event, be it objective or subjective is magnified and serves to further fuel the narratives which justify and rationalize mass death of the other. Denial has a profound negative impact on everyone concerned, especially the victims and their children. Furthermore, the denial of genocide goes beyond the manipulation, contradiction and/or re-interpretation of historical facts, it recreates the conditions under which new atrocities could occur.

While most of the interviewees felt that reconciliation required integrating an undetermined degree of denial on their part, they all insisted that acknowledgement by the perpetrator was imperative. Such acknowledgement, to a good enough level, must encompass the acknowledgement of the survivors' suffering and losses as well as making amends. More difficult to achieve, a good enough acknowledgement also implies the perpetrators' accountability for his or her misdeeds. However, the perpetrators' feelings of remorse and admission of guilt may not be guaranteed. Healing, imperative for both victims and perpetrators, could help lay the foundation for reducing the benefits linked to supporting denial; benefits such as political, economic and/or social gains. The necessary space and flexibility to counter denial cannot take place without top-down support as the socio-political context can impede such processes. A partnership between all levels of society must be developed to not only address the survivors' material and symbolic needs but also the structural and the material inequalities underlying the conflict. Only once the healing process begins, ${ }^{117} \mathrm{a}$ good enough acknowledgement becomes possible. To facilitate a good enough acknowledgement, peacebuilding initiatives and measures ought to look beyond the "good victim"/"bad perpetrator" dichotomy and be receptive to more than just the one exclusionary and silencing truth.

\footnotetext{
${ }^{116}$ Čehajić and Brown, "Silencing the Past."

${ }^{117}$ As argued previously (anonymous), the healing process is interlinked to the reconciliation process.
} 
Acknowledgement implies verbal and/or behavioral action, which goes beyond practical needs; it seeks to restore post-conflict relations as well. Acknowledgement is based on a fundamental transformation in one's perception of events where there is a shift from knowledge to acknowledgement, from exposure to events to understanding. It also reflects a shift in responsibility, not only for the perpetrator but also for the potential bystander as well. Indeed, one may not be morally responsible for failing to act when he or she lacks information about what is actually happening. It is only when a threshold of knowledge is met that we can begin to speak of a moral component: it is at this point that a person can no longer deny the evidence presented. Action then becomes possible, even when such actions do not directly or indirectly coincide with one's interests.

\section{Bibliography}

AFP, "Ties between Serbia and Bosnia remain fragile 20 years after war." Justice Info.net, July 11, 2015. Accessed April 17, 2016, http://www.justiceinfo.net/en/live-feed/1223-.html.

The Associated Press, "Serbian PM attacked at ceremony marking Srebrenica slaughter." CBS News, July 11, 2015. Accessed April 13, 2016, http://www.cbsnews.com/news/serbian-pmaleksandar-vucic-attacked-at-ceremony-marking-srebrenica-slaughter-in-bosnia/.

Agger, Inger. "Reducing trauma during ethno-political conflict: A personal account of psychosocial work under war conditions in Bosnia." In Peace, Conflict, and Violence: Peace Psychology for the $21^{\text {st }}$ Century, edited by Daniel J. Christie, Richard V. Wagner and Deborah A. Winter, 240-250. Englewood Cliffs: Prentice-Hall, 2001.

Al-Turkait, Fawziyah A. and Jude U Ohaeri. "Psychopathological status, behavior problems, and family adjustment of Kuwaiti children whose fathers were involved in the first gulf war." Child and adolescent psychiatry and mental health 2, no.1 (2008): 12. Accessed April 13, 2016), http://www.ncbi.nlm.nih.gov/pmc/articles/PMC2423353/pdf/1753-2000-2-12.pdf.

Baker, Graeme, "Russia criticised for vetoing UN Security Council resolution to condemn 1995 Srebrenica massacre as 'genocide'." Independent, July 8, 2015. Accessed April 13, 2016, http://www.independent.co.uk/news/world/europe/russia-criticised-for-vetoing-unsecurity-council-resolution-to-condemn-1995-srebrenica-massacre-as-10376244.html.

Bećirević, Edina. Genocide on the Drina River. New Haven: Yale University Press, 2014. http://dx.doi.org/10.12987/yale/9780300192582.001.0001

Bonta, James, Suzanne Wallace-Capretta and,Jennifer Rooney. Restorative justice: An evaluation of the restorative resolutions project. Ottawa: Solicitor General Canada, 1998.

Boscarino, Joseph A. "Posttraumatic stress disorder and physical illness: Result from clinical and epidemiologic studies." Annals of the New York Academy of sciences 1032, December (2004): 141-153. http://dx.doi.org/10.1196/annals.1314.011

Campbell, David. National Deconstruction: Violence, Identity, and Justice in Bosnia. Minneapolis: University of Minnesota Press, 1998.

Čehajić, Sabina and Rupert Brown. "Silencing the Past: Effects of Intergroup Contact on Acknowledgement of ingroup responsibility." Social psychological and personality science 1, no. 2 (2010): 190-196.

Čehajić, Sabina, Daniel A. Effron, Eran Halperin, Varda Liberman and,Lee Ross. "Affirmation, Acknowledgment of Ingroup Responsibility, Group-based Guilt, and Support for Reparative Measures." Journal of Personality and Social Psychology 101, no.2 (2011): 256-270. http://dx.doi.org/10.1037/a0023936

Čekić, Smail. Research of Genocide Victims, with a Special Emphasis on Bosnia and Herzegovina: Problems and Issues in Scientific Theory, Methods and Methodology. Sarajevo: Institute for the Research of Crimes Against Humanity and International Law of the University of Sarajevo, 2009.

The Center for Justice and accountability (CJA). Bosnia and Herzegovina: Torture and Ethnic Cleansing in the Bosnian War. CA, San Francisco: The Center for Justice and Accountability, 2014. Accessed March 5, 2015, http://www.cja.org/article.php?id=247.

Charny, Israel. "The psychology of denial: a contribution to the psychology of denial of genocide as a celebration of destructiveness, an attempt to dominate the minds of men, and a killing of history." Genocide and human rights: Lessons from the Armenian experience. A special issue of the journal of Armenian studies IV, no. 1-2 (2009): 289-306. 
Charny, Israel. "A classification of denials of the Holocaust and other genocides." In The genocide studies reader, edited by Samuel Totten and Paul R. Bartrop, 517-537. New York: Routledge, 2009.

Clark, Janine N. "From negative to positive peace: The case of Bosnia and Hercegovina." Journal of Human Rights 8, no.4 (2009): 360-384. http://dx.doi.org/10.1080/14754830903332434

Cohen, Stanley. States of Denial. Cambridge: Polity Press, 2013.

Cushman, Thomas. "Anthropology and genocide in the Balkans." Anthropological Theory 4, no.1 (2004): 5-28. http://dx.doi.org/10.1177/1463499604040845

Cushman, Thomas. “On Bosnia: Response to Hayden." Current Anthropology 40, no.3 (1999): 365-366. http://dx.doi.org/10.1086/200025

Dzidic, Denis, "Russia Vetoes UN Srebrenica Genocide Resolution." Balkan Transitional Justice, July 8, 2015. Accessed April 13, 2016, http://www.balkaninsight.com/en/article/russia-vetoesun-srebrenica-genocide-resolution.

Eagleburger, Lawrence. "The need to respond to war crimes in the former Yugoslavia." In The path to The Hague: Selected documents on the origins of the ICTY. Statement at the International Conference on the Former Yugoslavia, Switzerland, Geneva, December 16 1992. Accessed June 16, 2015), www.liv.ac.uk/library/sca/colldescs/owen/boda/fmin4.pdf.

Fletcher, Laurel E. and Harvey M. Weinstein. "Violence and Social Repair: Rethinking the contribution of justice to reconciliation." Human Right Quaterly 24, no.3 (2002): 573-639. http://dx.doi.org/10.1353/hrq.2002.0033

Gec, Jovana, Aida Cerkez, and, Dusan Stojanovic, "8 suspects arrested in Srebrenica massacre, including commander." Global news, March 18, 2015. Accessed April 13, 2016, http://globalnews.ca/ news/1888850/serbian-police-make-seven-arrests-linked-to-srebrenica-massacre/.

Giberovitch, Myra. "A drop-in center for holocaust survivors: Inspiring hope, meaning, and Purpose." Journal of Jewish Communal Service 75, no. 3-4 (2006): 239-247.

Green, Paula. "Reconciliation and forgiveness in divided societies: A path of courage, compassion, commitment." In Forgiveness and Reconciliation, edited by Anie Kalayjian and Raymond F. Paloutzian, 251-268. Santa Barbara: Springer, 2009. http://dx.doi.org/10.1007/978-1-4419$\underline{0181-116}$

Halilovich, Hariz. Places of Pain. New York: Berghahn Books, 2013.

Hirsch, Michele Lent. “Conflict Profile: Bosnia.” WMC's Women Under Siege Project. US: The Women's Media Center, 2012. Accessed February 11, 2015, http://www.womenundersiegeproject. org/conflicts/profile/bosnia.

Hamber, Brandon. Transforming societies after political violence. New York: Springer, 2010.

Hayden, Robert. "The tactical uses of passion in Bosnia." Current Anthropology 38, no.5 (1997): 924-926. http://dx.doi.org/10.1086/204686

Hayden, Robert. "Schindler's fate: Genocide, ethnic cleansing, and population transfers." Slavic Review 55, no.4 (1996): 727-748. http://dx.doi.org/10.2307/2501233

Herman, Edward S. "The Politics of the Srebrenica Massacre." Покрет за Србију (Movement for Serbia), February 23, 2008. Accessed April 7, 2016, http://pokretzasrbiju.org/the-politics-ofthe-srebrenica-massacre-by-edward-s-herman/.

Herman, Edward S. and David Peterson. The Politics of Genocide. New York: Monthly Review Press, 2011.

Herman, Judith. Trauma and recovery. New York: Basic Books, 1997.

Hewstone, Miles, Nicole Tausch, Alberto Voci, Jared Kenworthy, Joanne Hugues and Ed Cairns. "Why neighbours kill: Prior intergroup contact and killing of ethnic outgroup neighbours." In Explaining the breakdown of ethnic relations: Why neighbours kill, edited by Victoria M. Esses and Richard A. Vernon, 61-93, Malden: Blackwell Publishing, 2008. http://dx.doi.org/10.1002/9781444303056.ch4

Hirsch, Herbert. Genocide and the Politics of Memory. Chapel Hill and London: The University of North Carolina Press, 1995.

Hoare, Marko Attila. "Genocide in the former Yugoslavia: A critique of left revisionism's Denial." Journal of Genocide Research 5, no.4 (2003): 543-563. http://dx.doi. org/10.1080/1462352032000149495 
Hopkins, Valerie, "In the shadow of genocide." Foreign Policy, July 10, 2015. Accessed April 7, 2016, http://foreignpolicy.com/2015/07/10/in-the-shadow-of-genocide-srebrenica-bosnia/.

Horelt, Michel-André. "Serbia-Croatia, Bosnia and Herzegovina: Different apology packages, different successes." In Apology and Reconciliation in International Relations, edited by Christopher Daase, Stefan Engert, Michel-André Horelt, Judith Renner and Renate Strassner, 164-195. New York: Routledge, 2016.

Hutchison, Emma. Affective communities in world politics: Collective emotions after trauma. Cambridge: Cambridge University Press, 2016. http://dx.doi.org/10.1017/CBO9781316154670

JNBiH. Joint Report of the Justice Network in Bosnia and Herzegovina for the 2nd Universal Periodic Review on Human Rights Situation in Bosnia and Herzegovina. Sarajevo, 2014. Accessed April 11, 2016, http://www.mrezapravde.ba/mpbh/mpbh files/file/UPPreportFinalENG.pdf.

Johnstone, Diana. Fools' Crusade: Yugoslavia, NATO and Western Delusions. London: Pluto Press, 2002. Jones, Adam. Genocide: A Comprehensive Introduction, Second Edition. New York: Routledge, 2011.

Joseph, Stephen, Ruth William and William Yule. Understanding post-traumatic stress: A psychosocial perspective on PTSD and treatment. USA: Wiley, 1997.

Kalayjian, Anie S., Siroon P. Shahinian and Edmund L. Gergerian "Coping with Ottoman Turkish Genocide: an exploration of the experience of Armenian survivors." Journal of Traumatic Stress 9, no.1 (1996): 87-97. http://dx.doi.org/10.1002/jts.2490090108

Kellerman, Nathan P. E. Holocaust trauma: Psychological effects and treatment. New York: iUniverse, 2009. Langdridge, Darren. Phenomenological psychology: Theory, research and method. Harlow: PearsonPrentice Hall, 2007.

Lauterbach, Dean, Christina Bak, Sarah Reiland, Shawn Mason, Michael R. Lute and Lauren Earls. "Quality of parental relationships among persons with a lifetime history of posttraumatic stress disorder." Journal of traumatic stress 20, no.2 (2007): 161-172. http://dx.doi.org/10.1002/ jts.20194

Lechtholtz-Zey, Jaqueline. “The Laws Banning Holocaust Denial." Revised from GPN Issue 3, Genocide Prevention Now, Issue 9, Winter (2012). Accessed February 3, 2015,

http://www.genocidepreventionnow.org/Home/GPNISSUES/ GPNBulletinLAWSAGAINSTDENIALSpecialSection9/tabid/164/ctl/DisplayArticle/ mid/971/aid/470/Default.aspx.

Lemarchand, René. Forgotten genocides: Oblivion, denial, memory. University of Pennsylvania Press, 2011.

MDGF. Voices of youth: Survey on youth in BiH. MDG Achievement Fund: Sarajevo, 2012. Accessed April 15, 2016, http://www.ba.undp.org/content/bosnia and herzegovina/en/home/ library/democratic governance/voices-of-youth.html.

Nadler, Arie and Nurit Shnabel. "Instrumental and socioemotional paths to intergroup reconciliation and the needs-based model of socioemotional reconciliation." In Social Psychology of Intergroup Reconciliation: From Violent Conflict to Peaceful Co-Existence, edited by Arie Nadler, Thomas Malloy and Jeffrey D. Fisher, 37-57. New York: Oxford University Press, 2008. http://dx.doi.org/10.1093/acprof:oso/9780195300314.003.0003

Nettelfield, Lara J. Courting Democracy in Bosnia and Herzegovina: The Hague Tribunal's Impact in a Postwar State. New York: Cambridge University Press, 2012.

Reuters, "Russia vetoes Srebrenica genocide resolution at UN." The Guardian, July 8, 2015. Accessed April 13, 2016, http://www.theguardian.com/world/2015/jul/08/russia-vetoes-srebrenicagenocide-resolution-un.

Smith, Roger W., Eric Markusen and Robert Jay Lifton. "Professional ethics and denial of the Armenian genocide." Holocaust and Genocide Studies 9 no.1 (1995): 1-22. http://dx.doi.org/10.1093/hgs/9.1.1

Stanton, Gregory H. “Ten Stages of Genocide." Genocide Watch, 2013. Accessed April 11, 2016), http://www.genocidewatch.org/genocide/tenstagesofgenocide.html.

Stephan, Walter G., Lausanne C. Renfro and Mark Davis. "The role of threat in intergroup relations." In Improving intergroup Relations: Building on the legacy of Thomas F. Pettigrew, edited by Ulrich Wagner, Linda R. Tropp, Gillian Finchilescu and Colin Tredoux, 55-73. Malden: Blackwell Publishing, 2008. http://dx.doi.org/10.1002/9781444303117.ch5 
Tabeau, Ewa, Marcin Żołtkowski,, Jakub Bijak and,Arve Hetland. "Ethnic Composition, Internally Displaced Persons \& Refugees from 47 Municipalities of Bosnia and Herzegovina 1991 to 1997-8: Expert Report for the Case of Slobodan Milosevic, IT-02-54, 2003." In Conflict in Numbers: Casualties of the 1990s Wars in the Former Yugoslavia (1991-1999), edited by Ewa Tabeau, 661-875. Belgrade: Helsinki Committee for Human Rights in Serbia, 2009. Accessed June 17, 2015, www.helsinki.org.rs/doc/testimonies33.pdf.

UN ICTY. "Prosecutor v. Slobodan Milošević: Decision on Motion for Judgment of Acquittal," Kosovo, Croatia \& Bosnia, Case No. IT-02-54, 2004. Accessed February 1, 2015, www.icty. $\mathrm{org} / \mathrm{x} / \mathrm{cases} / \mathrm{slobodan}$ milosevic/tdec/en/040616.htm.

United States Holocaust Memorial Museum (USHMM). Confront Genocide-Cases-Bosnia Herzegovina. Washington DC: USHMM, 2015. Accessed May 8, 2015, http://www.ushmm. org/confront-genocide/cases/bosnia-herzegovina.

Vollhardt, Johanna Ray and Michal Bilewicz. "After the Genocide: Psychological Perspectives on Victim, Bystander, and Perpetrator Groups." Journal of Social Issues 69, no.1 (2013): 1-15. http://dx.doi.org/10.1111/josi.12000

Wertz, Frederick J., Kathy Charmaz, Linda M. McMullen, Ruthellen Josselson, Rosemarie Anderson and, Emalinda McSpadden. Five ways of doing: Qualitative analysis. New York: The Guilford Press, 2011.

Zwierzchowski, Jan and,Ewa Tabeau. "The 1992-95 War in Bosnia and Herzegovina: CensusBased Multiple System Estimation of Causalities' Undercount." Conference Paper for the International Research Workshop on The Global Costs of Conflict. Berlin: The Households in Conflict Network and The German Institute for Economic Research, 2010. Accessed April 5, 2016, http://www.icty.org/x/file/About/OTP/War Demographics/en/bih casualty undercount conf paper 100201.pdf. 